\title{
Some aspects of sugar nutrition of excised embryos of Lupinus luteus L. and Brassica oleracea L.
}

\author{
A. HOFFMANNOWA
}

Sugars are perhaps among the most important metabolites used in the in vitro culture of embryos. A great number of sugars, ranging from pentoses to polysaccharides have been tested in cultures. The data available comes from work on a variety of tissues and organs as well as embryos. It has often been stated that different types of sugars may not have the same significance in nutrition. Many investigators consider sucrose to be the best source of carbon and energy in plants (v a n O v e rbeek and al. 1944; Dormer and Street 1949; Lee 1950; Street and Lowe 1950; Rijven 1952).

There is considerable difference of opinion in relation to the function of glucose and fructose, which cannot easily be explained by differences in technique employed. Fructose is considered toxic by $\mathrm{Brannon}$ (1923) and White (1940), but was found to stimulate growth in the experiments of $\mathrm{Slank}$ is (1948) and Le e (1950) In general it may be considered on the basis of the reports available that some of the naturally occuring sugars inhibit the development of embryos, tissues and organs cultured in vitro. This inhibitory influence may even be toxic. Galactose is considered a typical example of a sugar which may have toxic properties (Burström 1948; Gimesi and al. 1950; Street and Lowe 1950; Farkas 1954).

The influence of added sugars an the growth of embryos deprived of cotyledons or of their endosperm is of interest in this type of work. In the present case different sugars were added to the culture medium of mature excised embryos. Two plants Lupinus and Brassica, which differ in the materials stored in their cotyledons were chosen for these experiments.

\section{MATERIAL AND METHODS}

Seeds of yellow lupine, Lupinus luteus L. var. "Express" and of white cabbage, Brassica oleracea L. var. capitata f. alba "Amager" were used. The lupine seeds were obtained from the Research Centre of the Institute of Soil Science, Plant Cultivation and Manuring at Przebędowo. The cabbage seeds came from the E. Freege pure line at Mizerów. 
Table 1

\begin{tabular}{l|c|c|c}
\hline & Weight of 1000 seeds & Per cent germination & Water content \\
\hline Lupine & $114.37 \mathrm{~g}$ & $99.3 \%$ & $9.1 \%$ \\
\hline Cabbage & $2.35 \mathrm{~g}$ & $95.3 \%$ & $6.9 \%$ \\
\hline
\end{tabular}

Table 2

Percentage content of

\begin{tabular}{|c|c|c|c|c|c|c|}
\hline & \multirow{2}{*}{ protein $\mathrm{N}$} & \multirow{2}{*}{ proteins } & \multirow{2}{*}{ fat } & \multicolumn{3}{|c|}{ sugars } \\
\hline & & & & reducing & soluble & total \\
\hline Lupine & 5.23 & 32.7 & 3.75 & 1.56 & 1.50 & 3.74 \\
\hline Cabbage & 2.53 & 15.9 & 33.71 & 1.50 & 1.50 & 3.32 \\
\hline
\end{tabular}

The chief characteristics of this seed material are summarized in the tables 1 and 2 .

Sugar, protein-N and fat content in seed was determined on dried, powdered material. Protein- $\mathrm{N}$ was determined by the micro-Kjeldahl method. The figure for the amount of protein present in seeds was obtained by multiplying the protein- $\mathrm{N}$ figure by the coefficient 6,25 .

The sugar analyses included all the easily metabolised fractions i.e. soluble sugars (both reducing and nonreducing) and hydrolizable polysaccharides. The sum of all these fractions is further referred to as "total sugars". Sugar content analysis was carried out using the micro-method of $\mathrm{H}$ a gedorn and $\mathrm{J}$ ensen modified by $\mathrm{Fujita}$ and $\mathrm{I}$ watake (Brzeski, Kaniuga 1957).

Fats were extracted with ethyl ether using the Haanen-Badum apparatus.

In preparing for excision of embryos seeds were washed with absolute ethanol for 1 minute, sterilized with $0,2 \%$ mercuric chloride and finally rinsed thrice with sterile water. They were then soaked in distilled water for 18 hours. The excised embryos were then placed in individual culture tubes. The lupine embryos were pushed into the culture medium so that a few milimeters of the radicle were submerged. There were 2 lupine embryos to a culture tube. The cabbage embryos were smaller and were placed on the surface of the medium. There were 4 cabbage embryos to a culture tube.

The basal medium (used as control) contained agar and half strength Knop's solution. Different concentrations of the following sugars were 
added to the basal medium in successive experiments: arabinose, xylose, glucose, fructose, galactose, sucrose, maltose and raffinose. The cultures were kept in the dark in a thermostat at $25^{\circ} \mathrm{C}$ for 7 days. The embryos were then taken out of the culture tubes and the length of the hypccotyls and roots was measured. The fresh weight of roots and hypocotyls was determined separately. The material was then dried for $12 \mathrm{hrs}$ at $105^{\circ} \mathrm{C}$ for dry weight determination.

Results are presented in graphs shown in the figures. Each point on a graph eg. one concentration of a given sugar, is the mean of $2-3$ replicates. Each replicate included 48 embryos. The range of the standard error of the mean for measurements (in $\mathrm{mm}$ ) on cabbage embryos was:

$$
\begin{aligned}
& \pm 1,4- \pm 1,7 \text { for roots } \\
& \pm 0,4- \pm 0,9 \text { for hypocotyls }
\end{aligned}
$$

In lupine embryo measurements the range of the standard error of the mean was:

$$
\begin{aligned}
& \pm 0,2- \pm 2,4 \text { for roots } \\
& \pm 0,2- \pm 1,2 \text { for hypocotyls }
\end{aligned}
$$

The number of embryos discarded due to abnormalities or to infection was less than 1 per cent.

In the graphs presented the concentrations of the test substances added to the culture medium are given on the abscissa. The length in $\mathrm{mm}$ and fresh weight in $\mathrm{mg}$ are shown on the left ordinate, the dry weight in $\mathrm{mg}$ is shown on the right ordinate. Values above the zero level refer to one hypocotyl, those below refer to one root. This scheme applies to all the graphs presented.

The reagents used were supplied by: arabinose, mannitol, maltose, raffinose (Hoffman La Roche); fructose, xylose - Light (England); galactose - Lachema (CSSR). Other reagents were supplied by Gliwice (Poland).

\section{RESULTS}

Preliminary tests to determine the optimum number of embryos per tube were carried out. Growth was expected to be weaker with the increasing number of embryos per tube, due to rapid exhaustion of nutrients in the medium. The basal medium contained 0.75 per cent agar, half strength Knop's solution and 4 per cent sucrose. Lupine embryos were used due to their larger size. The numbers tested were 1, 4 and 10 embryos per tube respectively. These embryos were cultured for a period of 14 days and the tests were repeated four times. 


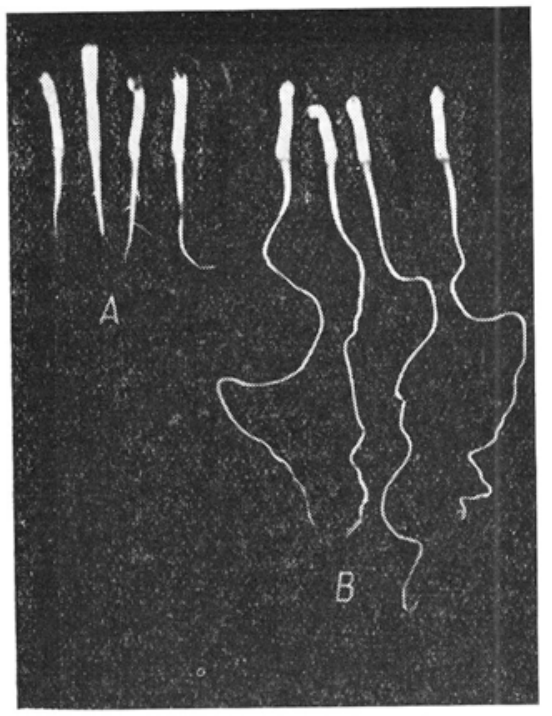

Photo 1. Embryos cultured for 14 days with 4 per cent sucrose in the medium.

$A-1$ embryo per culture tube; $B-10$ embryos per culture tube.

Results in all tests were almost identical. Best growth in lupine embryos was obtained in cultures with ten individuals per tube. This is especially evident in the case of the roots as is shown in photo 1 .

Length of embryo hypocotyls and roots

\begin{tabular}{l|c|c}
\hline & Number of embryos per tube \\
\cline { 2 - 3 } & 1 & 10 \\
\hline $\begin{array}{l}\text { Mean hypocotyl } \\
\text { length in mm }\end{array}$ & 17 & 12 \\
\hline $\begin{array}{l}\text { Mean root } \\
\text { length in mm }\end{array}$ & 23 & 95 \\
\hline
\end{tabular}

On the basis of these tests it was decided to use 4 embryos per culture tube for cabbage and 2 embryos per culture tube for lupine.

1. The influence of osmotic concentration on growth

The effect of culture media at different osmotic concentrations on the growth of lupine and cabbage embryos was studied. The following variations in the basal medium were employed:

I. Basal medium + different concentrations of sucrose.

II. Basal medium + different concentrations of $\mathrm{NaCl}$.

The amounts of sodium chloride added were adjusted so that they would give the same osmotic concentration as the successive sucrose per cent concentrations. The correct quantities were obtained from Walter's tables (W a l ter 1936). 
III. Basal medium +4 per cent sucrose $+\mathrm{NaCl}$.

The amounts of sodium chloride used to give a series of increasing osmotic pressures are given in tab. 3 .

Table 3

\begin{tabular}{c|c|c}
\hline Per cent sucrose & NaCl in $\mathrm{g} / 100 \mathrm{ml}$ medium & $\begin{array}{c}\text { Osmotic equivalent to } \\
\times \text { per cent sucrose }\end{array}$ \\
\hline 4 & 0.087 & 5 \\
4 & 0.181 & 6 \\
4 & 0.277 & 7 \\
4 & 0.374 & 8 \\
4 & 0.470 & 9 \\
4 & 0.572 & 10 \\
4 & 0.680 & 11 \\
4 & 0.780 & 12 \\
\hline
\end{tabular}

IV. Basal medium +4 per cent sucrose + mannitol in different per cent concentrations.

Results obtained are shown in figs $1,2,3,4,5,6,7,8$. There was a conspicuous difference in the response of lupine and cabbage embryos to the addition of the same substances to the medium. There was no increase in length in lupine hypocotyls on sucrose media. The dry weight increased with increasing sucrose concentrations. Cabbage embryos reacted positively to the addition of sucrose. The presence of sodium chloride in different concentrations had a similar effect on the embryos of both species.

When the medium contained 4 per cent sucrose and sodium chloride in increasing concentrations the reaction of the two plants differed. When the osmotic concentration was equivalent to 7 per cent sucrose the values reached for the length, fresh and dry weight of lupine hypocotyls were higher than those obtained in the presence of any other sugar. The highest values for roots were reached at a 10 per cent sucrose osmotic equivalent. Cabbage embryos reacted differently. All the values except root length decreased with increasing osmotic concentration.

Mannitol was used in basal medium IV because of its osmotic function and metabolic neutrality. The response of the two species was different also in this case.

\section{The effect of added sugars on growth}

A. Pentoses

Different concentrations of xylose and arabinose were tested. Xylose inhibited hypocotyl growth in both lupine and cabbage as its concentration increased $(0-3,0$ per cent). In lupine root length increased to the same extent as at an equivalent sucrose concentration. In cabbage the 
inrease in root length was less than that in equivalent sucrose concentrations (Fig. 9, 10).

Arabinose was tested at the same concentrations as xylose. Arabinose had an inhibitory effect on growth in both cabbage and lupine (Fig. 11, 12). As the concentration increased light-brown spots appeared on lupine

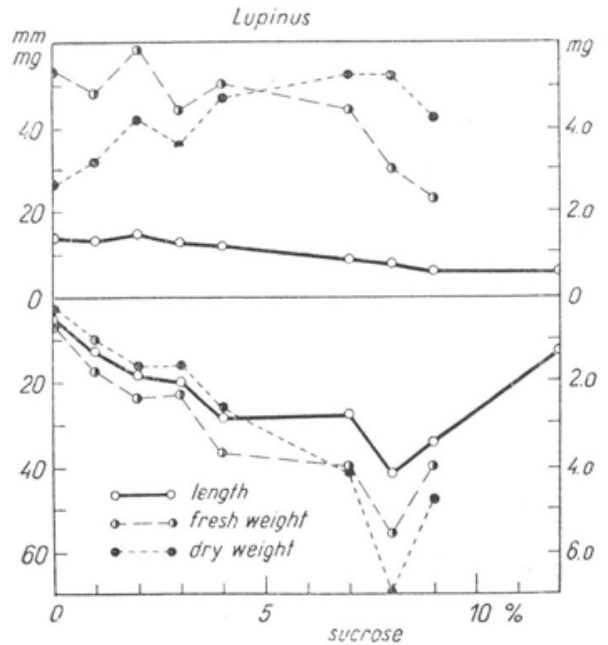

Fig. 1

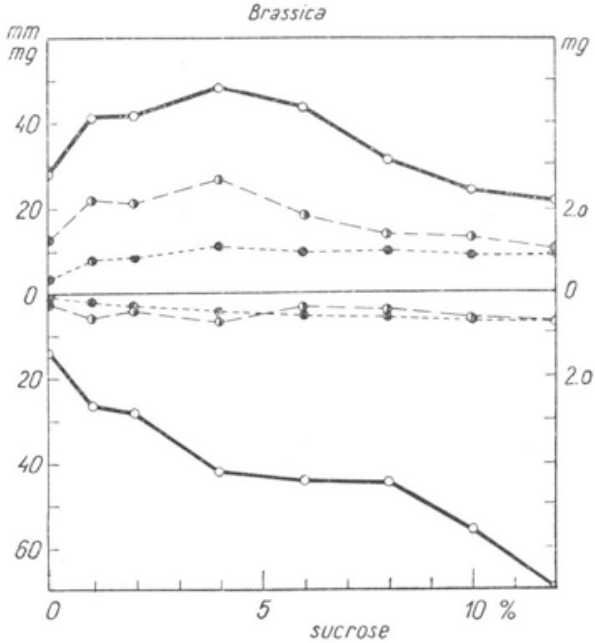

Fig. 2

hypocotyls which then became glassy. Roots aquíred a similar light brown colouring and lost turgor. In cabbage embryos a swelling appeared at the root-collar.

After 7 days growth a part of the embryos was reinoculated onto a new medium containing 4 per cent sucrose. The reinoculated embryos

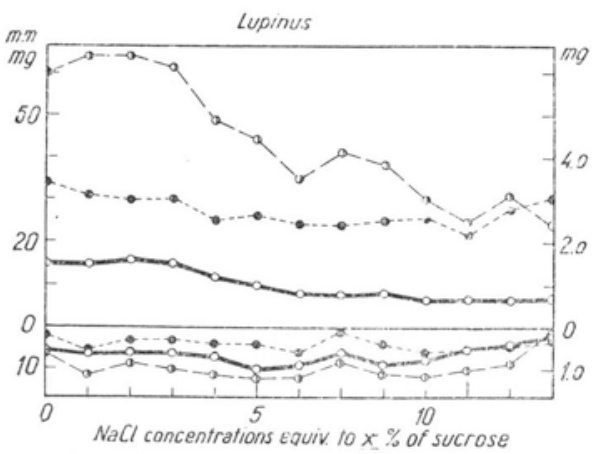

Fig. 3

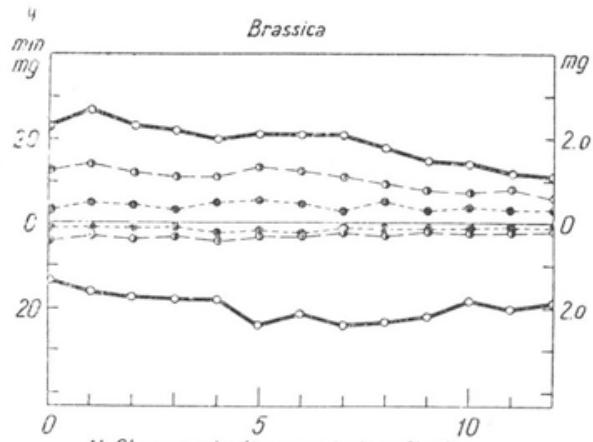

$\mathrm{NaCl}$ concentrations equiv to $x \%$ of sucrose

Fig. 4

were cultured for a further 7 days. At the end of this period it was observed that the cabbage embryos transferred form the lower arabinose concentrations (up to 1.5 per cent) had very small plumules and a few 


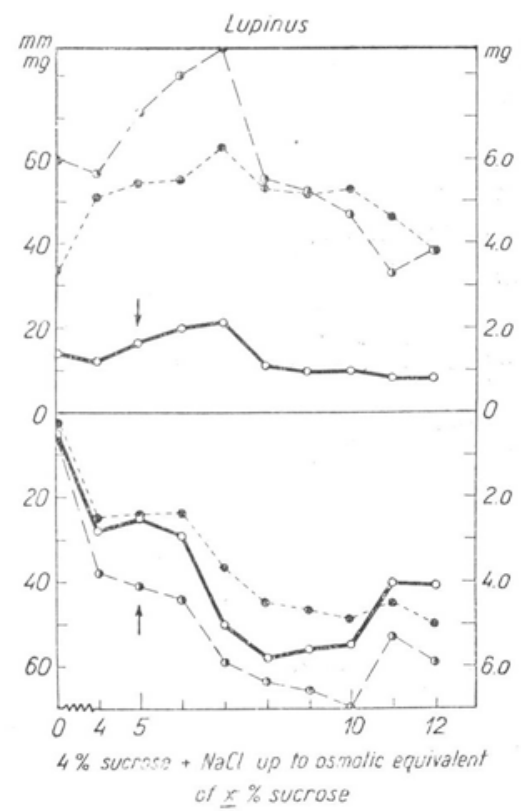

Fig. 5

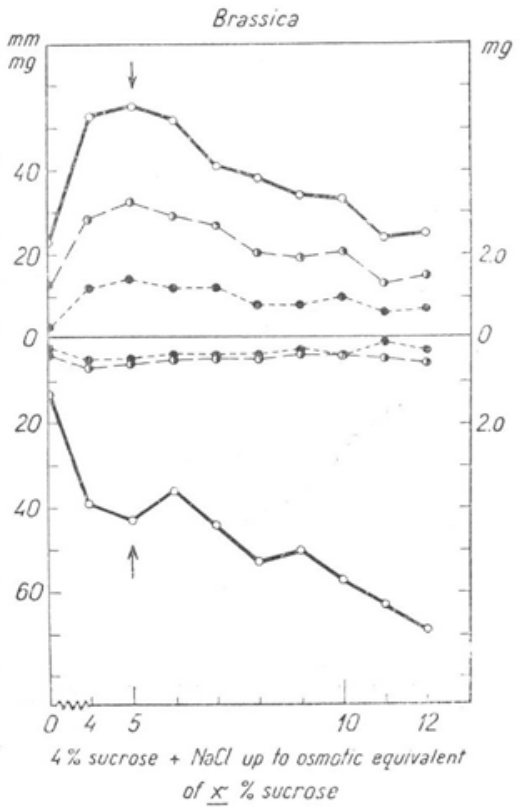

Fig. 6

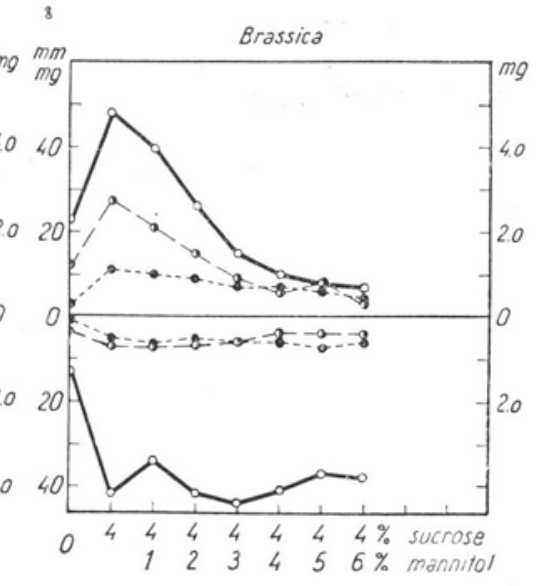

Fig. 3

Fig. 7

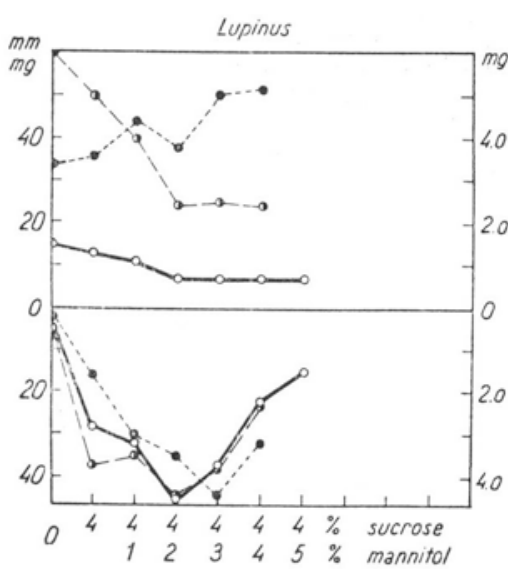

short lateral roots. No changes were noticed in embryos transferred from the higher concentrations. Lupine embryos formed adventitious roots just above the root-collar or in the upper parts of the hypocotyl.

To test the possibility that arabinose has a toxic effect in lupine and cabbage embryos, additional experiments were carried out using nutrient media with 4 per cent sucrose and increasing arabinose concentrations $(0.5-3.0$ per cent) (Figs 13,14$)$. Only lupine showed a significant reaction since the root length as well as fresh and dry weight increased. There were no dark spots present in lupine hypocotyls in this case. 


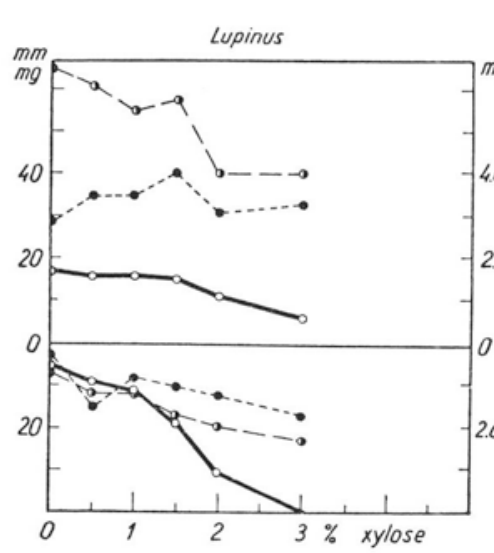

Fig. 9

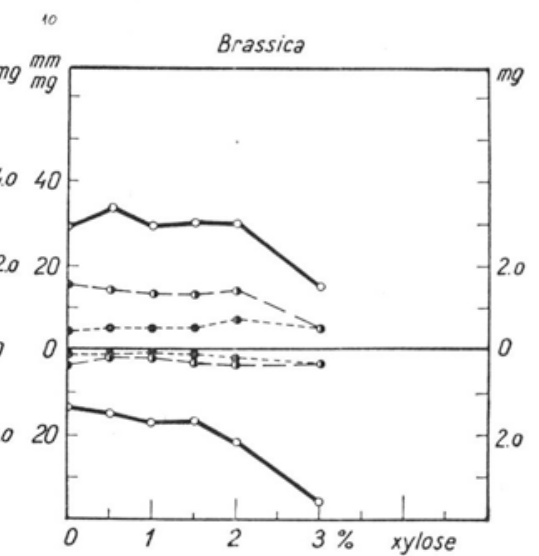

Fig. 10

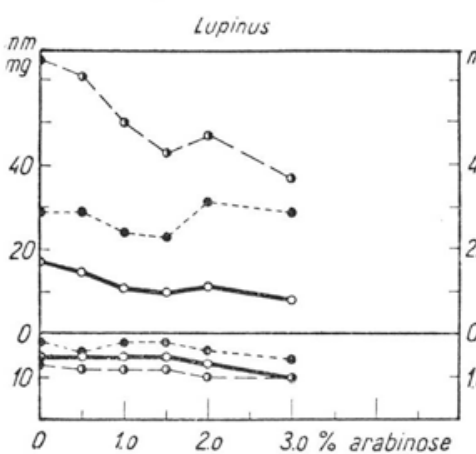

Fig. 11

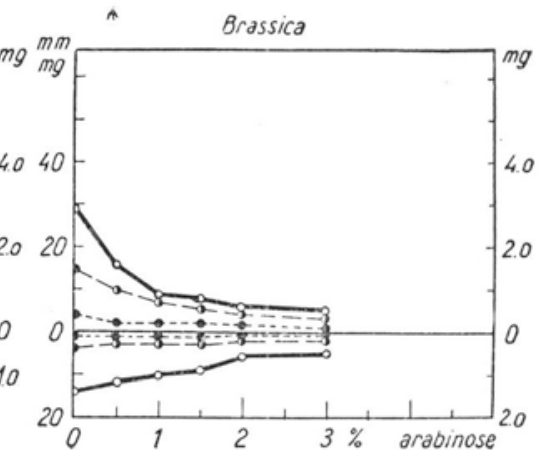

Fig. 12

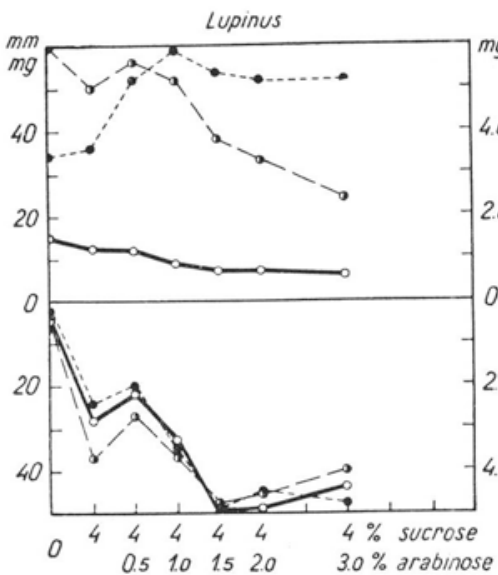

Fig. 13

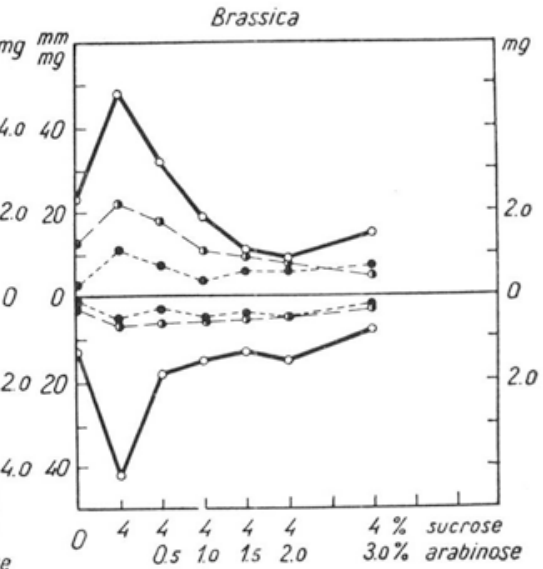

Fig. 14

Cabbage embryos reacted differently. A large number of lateral roots appeared next to the root collar and often grew to a greater length than the main root. 
B. Hexoses

Glucose, fructose and galactose were tested. In lupine embryos the stimulatory effect of glucose resulted in an increased dry weight of hypocotyls. The roots showed an increase in dry and fresh weight as well

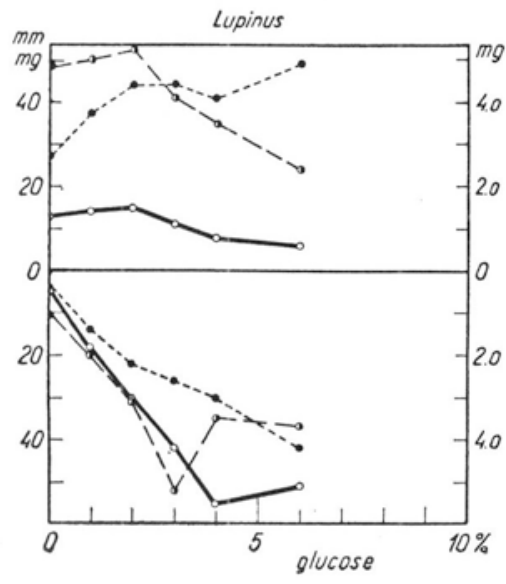

Fig. 15

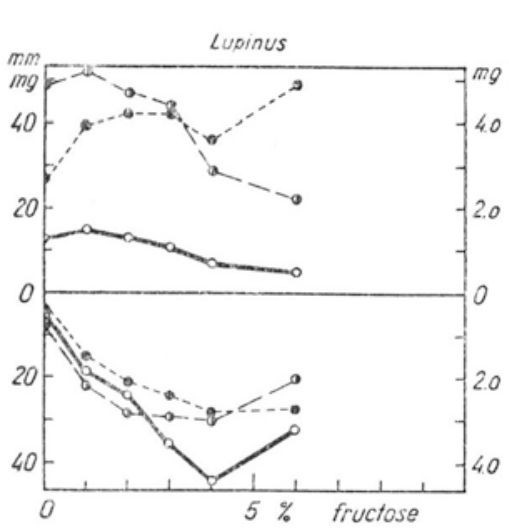

Fig. 17

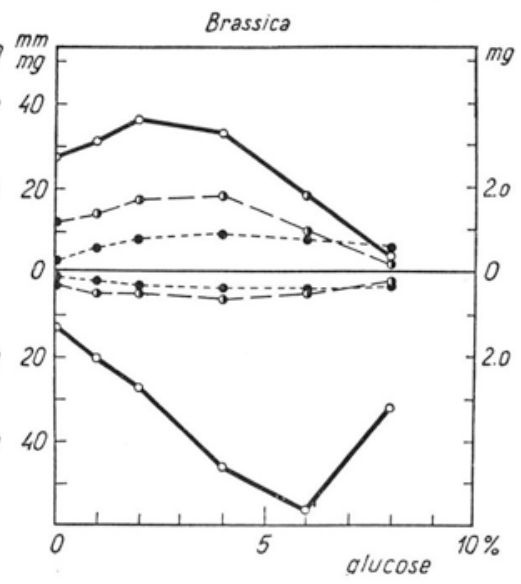

Fig. 16

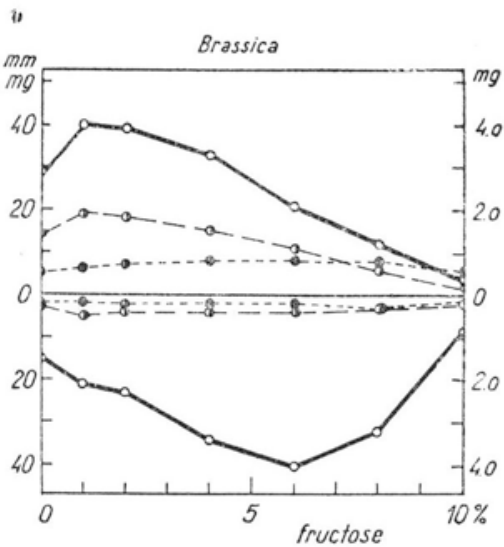

Fig. 18

as an increase in length. In cabbage embryos both hypocotyl and root growth were stimulated. Similar results were obtained when fructose was used (Fig. 15-18).

Lupine embryos did not grow uniformely in media with 6 and 8 per cent glucose. It was found possible to divide them into size groups mainly on the basis of root length (photo 2). One of these groups contained embryos which were no longer than freshly excised ones. Lupine embryos grown on 6 and 8 per cent fructose showed the same size gradation. Cabbage embryos did not react in this way.

Embryos which had not exceeded the initial size on fructose and 


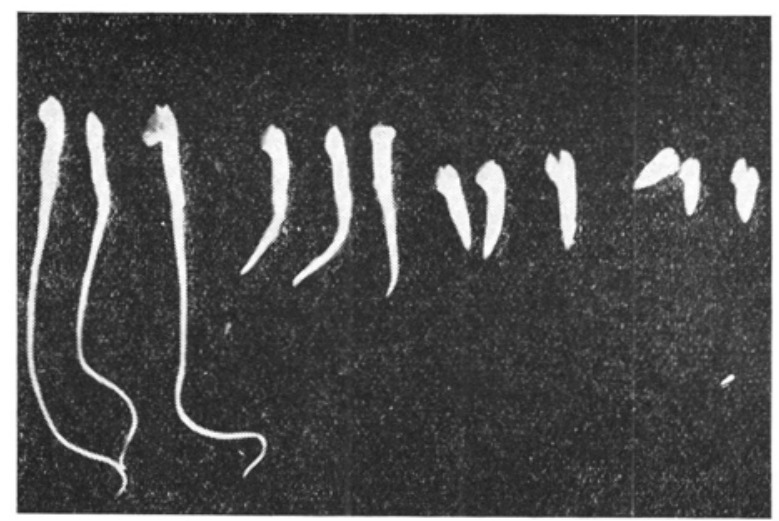

Photo 2. Embryos cultured for 7 days on medium with 8 per cent glucose.

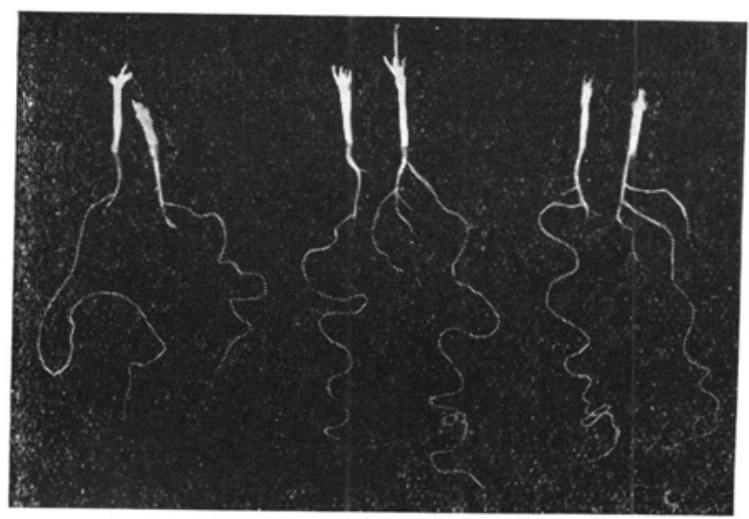

Photo 3. Embryos transferred from media with 8 per cent glucose and fructose to a medium with 4 per cent sucrose and cultured on this medium for three weeks.

glucose media were transferred to a medium with 4 per cent sucrose after 7 days growth and cultured at $25^{\circ} \mathrm{C}$ in the dark for three weeks. Further development of those embryos was satisfactory as is shown in photo 3. Very long lateral roots were produced, but growth of main roots was weak.

This result is unusual in so far as lateral roots are not readily formed by decotylised embryos even in optimal media. Fries (1960) is of the opinion that a factor responsible for lateral root formation is removed with the cotyledons. In the present work it was found possible to obtain the formation of laterals by changing the sugar concentration. The type of sugar used seemed less important than the concentration.

The action of galactose, the last sugar studied, was inhibitory even toxic to lupine and cabbage embryos. Large dark brown spots which reached deep into the tissues appeared on lupine hypocotyls. The whole of the central cylinder was brown. The roots turned dark brown and 


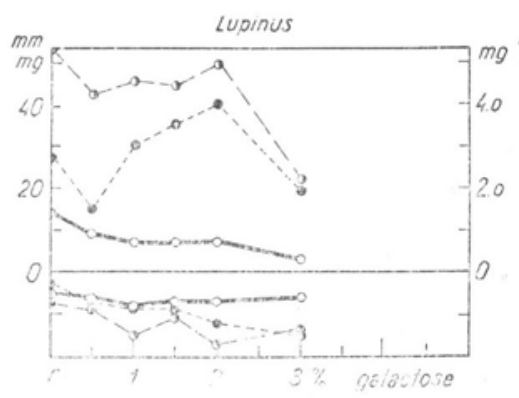

Fig. 19

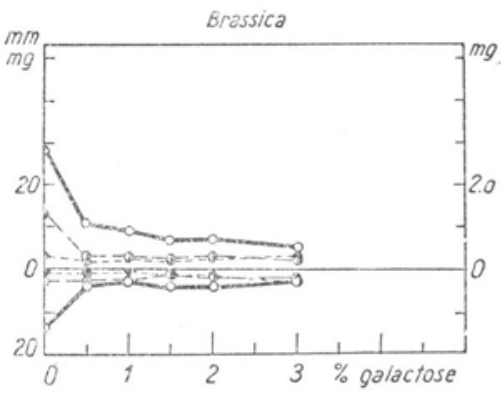

Fig. 20

this colouring was also visible in cross sections. Roots became thicker, harder and brittle but root tips lacked turgor. The reaction observed in cabbage embryos was similar but the hypocotyls did not turn brown and the only additional colouring were black spots at the points where the cotyledons had been attached (Figs 19,20).

Some further experiments were carried out as was done after the tests with arabinose. A part of the embryos from cultures at different concentrations of galactose was reinoculated onto media containing 4 per cent sucrose. After 7 days growth it was observed that embryos produced laterals only in isolated instances. No more than two laterals were then produced.

In both lupine and cabbage, in media containing 4 per cent sucrose and amounts of galactose increasing from $0.5-3.0$ per cent, growth was less than that of the controls (Figs 21,22). In lupine roots values exceeded those of the controls at the lower concentrations and there was an increase in dry weight in the hypocotyls. The appearence of the embryos was unchanged. The hypocotyls showed dark spots and roots were dark brown.

In order to obtain an clearer understanding of the changes arising in embryos after the addition of galactose some anatomical sections were studied. Lupine and cabbage embryos cultured in media containing 4 per cent sucrose, 3 per cent galactose and no sugar at all were fixed in Carnoy. Sections $(12 \mu)$ were stained with tannin and ferric chloride (S a s S 1958).

Longitudinal and transverse sections of embryos cultured in media without sugar or containing 4 per cent sucrose were anatomically similar. The meristematic region in root tips was quite long and distinct. The distribution and the development of tissues in the embryo was normal and uniform. Some differences were observed in logitudinal and transverse sections of embryos from cultures containing 3 per cent galactose.

The parenchyma cells of both roots and hypocotyls were smaller. The meristematic region of the root tip was much shorter and dark. 


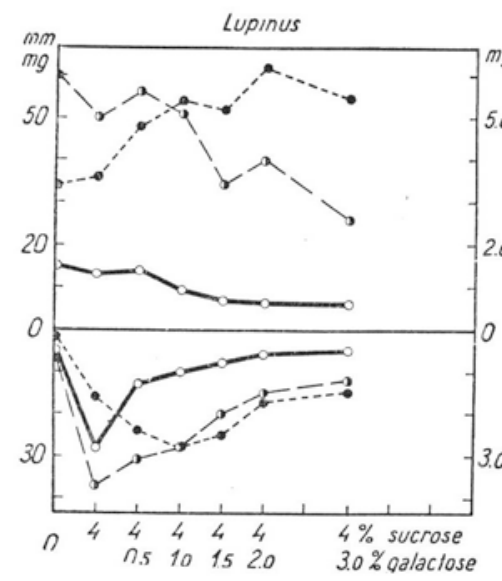

Fig. 21

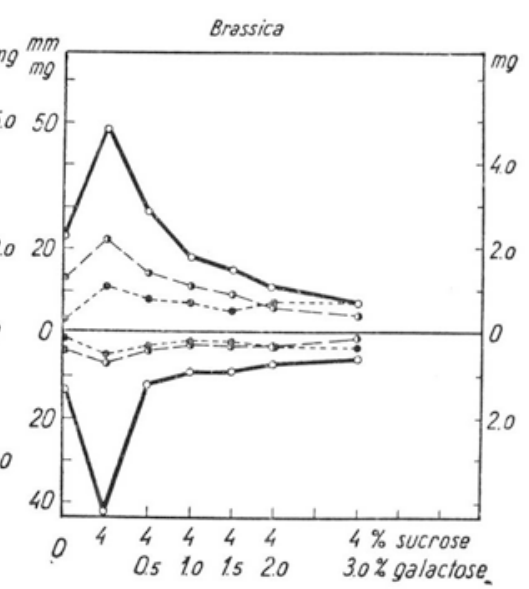

Fig. 22

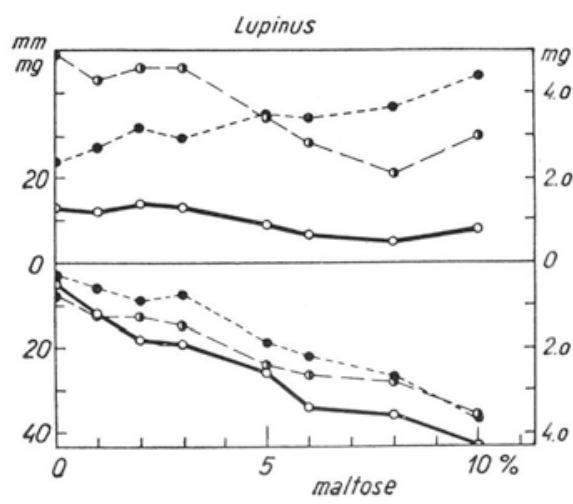

Fig. 23

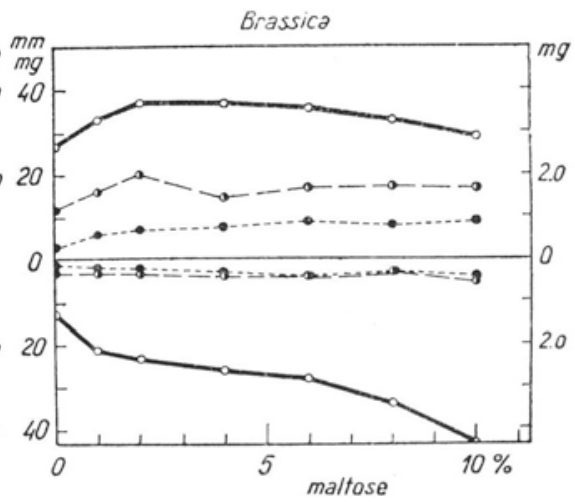

Fig. 24

Cell walls in the central cylinder and within the vascular strands were thickened and very dark, even black, particularly in roots. Cracks were noticeable within the central cylinder of the root. The middle lamellae of the cortex parenchyma in roots seem to have been dissolved so that in both logitudinal and transverse sections one can see free, loose-lying cells surrounded by an epidermis which is not always continuous. All lupine embryos from galactose cultures showed a furrow running along the whole length of the hypocotyl from the root-collar. This furrow was visible as a deep incision in transverse sections of lupine hypocotyls.

C. Oligos a c charides

Sucrose, maltose and raffinose were tested. Cabbage embryos were stimulated by the addition of sucrose to the medium. Root length increased while root fresh and dry weights remained more or less unchanged. In lupine embryos only root growth was stimulated. In hypocotyls the increase in length and fresh weight was inhibited but dry mass rose. 


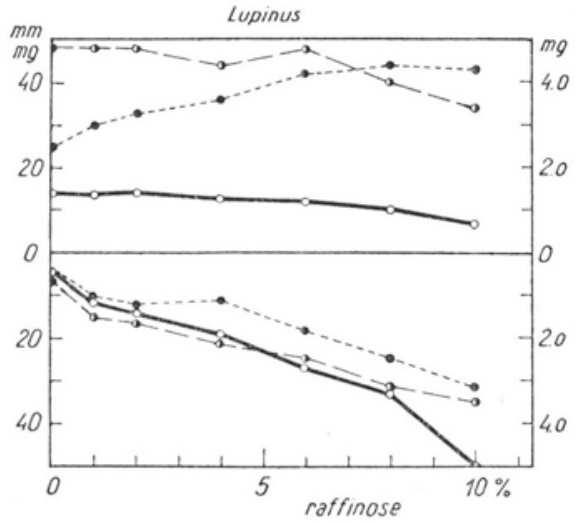

Fig. 25

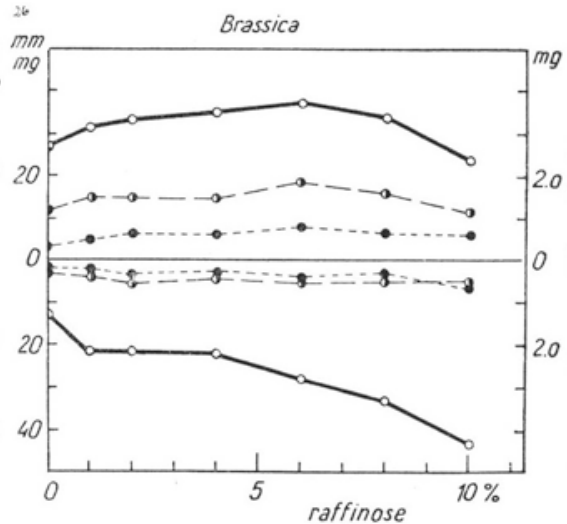

Fig. 26

The reaction of cabbage embryos to the addition of maltose was similar but the stimulation was smaller than in sucrose cultures. This was also the case in lupine embryos (Figs 1,2,23,24).

When raffinose was added to culture media cabbage embryos gave higher growth values than the controls. This chiefly concerned an increase in length. In lupine embryos roots increased in length, fresh and dry weight but in hypocotyls only the dry weight rose (Figs 25,26).

\section{DISCUSSION}

The results obtained agree with the generally accepted view, that sucrose is the best source of carbon and energy for plant tissues and embryos. Both cabbage and lupine embryos showed best growth on sucrose media. While in cabbage embryos hypocotyls as well as roots were markedly stimulated, in lupine embryos growth was good but weaker than in the former species.

When the added sugars were xylose, glucose, fructose, and raffinose the reaction of lupine embryos was also less than that of cabbage embryos. It is possible that in lupine embryos, which are relatively large, the period of 7 days culture is not sufficiently long to exhaust storage materials. Development can be more independent of added nutrients inspite of the lack of cotyledons.

There is a difference between the reaction of hypocotyls and roots in both species. The optimal sugar concentrations for hypocotyls are lower and those for roots are higher. Differences between hypocotyl and root metabolism may be responsible. This suggestion is based on the fact that optima for isolated roots have been known to be lower than root optima in whole embryo culture (S zweykowska 1963).

The response of cabbage and lupine embryos to osmotic concentration in the medium is also different. Lupine embryo growth does not seem 
to be affected by higher osmotic concentrations. In media with 4 per cent sucrose and sodium chloride the values for length, fresh and dry weight were the highest obtained during the course of this work. Although the effect of sodium chloride is often considered toxic (U h vits 1946) in this particular case there may be a positive chemical effect of these ions. This reaction was not observed in cabbage embryos.

No confirmation was found for the view that fructose may have a toxic action. Both lupine and cabbage embryos developed satisfactorily in media containing glucose or fructose. The reaction of the cabbage embryos was more distinct in that both sugars definitely stimulate growth. The appearence of the size groups when lupine embryos are grown on 6 and 8 per cent glucose or fructose (this does not occur in cabbage) should not be attributed to the toxic action of these sugars. This is a case of an initial inhibition of growth which was observed to disappear when the smallest embryos were transferred to a fresh medium with 4 per cent sucrose. Growth after transfer was good and long lateral roots were formed. This effect therefore can in no way be compared to the toxic action of arabinose and galactose which cannot be eliminated by the addition of sucrose to the medium or by transfer to a medium containing sucrose only.

In this work the toxic properties of galactose and arabinose resulted in a strong growth inhibition. Brown spots appeared on lupine hypocotyls and the roots coloured dark brown, becoming hard and brittle. $\mathrm{S}$ te $\mathrm{n} \mathrm{lid}(1959 \mathrm{a}, 1959 \mathrm{~b})$ mentions that it was possible to anihilate the harmful effects of galactose in isolated roots in in vitro culture by addition of glucose to the medium. He reports that galactose affected phosphate, nitrate and chloride uptake and that this action may differ with the variety as well as with the species used. In later work (Stenlid, Danckward't-Lilienström 1961) the same authors state that isolated cucumber roots may to some distinct extent utilize galactose as a source of carbon. F a rkas (1954) considers the toxicity of galactose a more general phenomenon, applicable to a wide range of plants and independent of species. The present results agree with those of $\mathrm{F}$ a r k a s in relation to both galactose and arabinose action. Arabinose also had a toxic effect although its action was weaker.

The spatial configuration of the molecules of the toxic sugars may be connected with their properties. According to the experiments of $\mathrm{C} z$ osnow ski (1962) galactose is taken up by the embryos much more quickly than sucrose. This would explain the present observation that the addition of sucrose to the medium did not counteract the toxic action of galactose.

Anatomical observations confirm the view expressed by Alls $0 \mathrm{pp}$ $(1953,1954,1955)$ that sugar action chiefly affects the meristematic region resulting in either a stimulation or an inhibition of divisions. In the 
present work the meristematic region in roots of embryos cultured in galactose media was very short. Burström (1948) reports that in galactose medium the meristematic region in the cultured isolated wheat roots was dark and opaque and the cytoplasm was coagulated. F a r k a s (1954) also mentions coagulated cytoplasm.

It is still very difficult to theorize about the mechanism of toxic action of such sugars as galactose. Galactose may produce its effect through a competitive inhibition mechanism but it is also possible that roots lack enzymes which would transform this sugar into a metabolically suitable form according to the system reported in Saccharomyces fragilis (Garner, Grannis 1951). In that case galactokinase in the presence of ATP acted to give rise to 1-P-galactose which was subsequently transformed to 1-P-glucose by the action of phosphogalactoisomerase.

The present results show a distinct difference in the reaction of lupine and cabbage embryos. The two plants show a different course of development when cultured in vitro even when the same medium is used. It may be supposed that the whole course of metabolism in these plants is different, leading to the formation of proteins as the chief storage material in lupine and fats in cabbage. It is equally possible to consider that the important metabolic differences are restricted to the early developmental phases since different storage materials may be mobilized in the two plants when growth starts. This may be a difference in the sequence in which the different storage materials are mobilized.

In lupine there is a difference in the maximum growth possible which depends on whether there are 10 embryos per tube or only one embryo per tube. Substances liberated into the medium by roots may be involved. A great variety of substances which may by excreted into the substrate by roots is known (W o o d s 1960, B ö rne r 1960). Substances reported by the above authors had an inhibitory effect. Any further investigation would require detailed and lengthy biochemical analysis.

The effect discussed was observed in lupine embryos and not in cabbage embryos. It is possible that lupine embryos synthesize limited quantities of one or more substances which are essential metabolites. The embryos are leached of these substances when they are liberated into the substrate. This may cause a deficiency of the metabolites concerned. When there are 10 embryos per culture tube the saturation of the medium by these substances occurs sooner and further exodiffusion stops sooner. There is no further depletion of essential substances in the embryo and better growth follows. When there is only 1 embryo in the culture tube exodiffusion continues longer since more time is required to saturate the medium. Further work will be conducted for the purpose of elucidating this problem. 


\section{SUMMARY}

The influence of eight different sugars on mature excised lupine and cabbage embryos was investigated. The embryos were cultured in vitro in the dark.

1. Both lupine and cabbage embryos develop best in culture media in which sucrose is the carbon source. In cabbage embryos the reaction is an evident stimulation while in lupine embryos the reaction is weaker. The same difference in the reaction of the two plants was observed when the sugars added were xylose, glucose, fructose, maltose or raffinose. Cabbage embryo roots give a stronger response than lupine embryo roots.

2. Hypocotyls and roots react differently. The optimum concentrations for hypocotyls are lower and those for roots higher.

3. Lupine embryos are less affected when the osmotic concentration of the medium is raised than cabbage embryos.

4. Fructose and glucose are not toxic to the embryos. There is some growth inhibition at higher concentrations of these sugars which disappears when the embryos are transferred to a new medium containing 4 per cent sucrose.

5. Arabinose and galactose have a distinctly toxic action which is weaker and less evident in the case of arabinose. Toxicity symptoms are not eliminated when the embryos are transferred to a medium with 4 per cent sucrose.

6. Lupine and cabbage embryos react differently to the addition of the same substances to the culture medium.

7. In lupine there is a difference in the maximum growth possible which depends on whether there are 10 embryos per tube or only one embryo per tube. When there are 10 embryos per tube growth, particularly root growth is much better. This was not observed in cabbage embryos.

Department of Plant Physiology,

University of Poznan,

Poznań, Stalingradzka 14.

(Entered: 20.6.1963)

\section{REFERENCES}

A $11 \mathrm{~s}$ op p A., 1953, Investigations on Marsilea: The effect of various sugars on development and morphology, Ann. Bot. 17:447-463.

A 11 s op p A., 1954, Investigations on Marsilea: Anatomical effects of changes in sugar concentration, Ann. Bot. 18:449-461.

A 11 s opp A., 1955, Investigations on Marsilea: Cultural conditions and morphogenesis with special references to the origin of land and water forms, Ann. Bot. 19:248-264.

Börner H., 1960, Liberation of organic substances from higher plants and their role in the soil sickness problem, Bot. Rev. 26:393-424.

Brannon J. M., 1923, Influence of certain sugars on higher plants, Bot. Gaz. $75: 370-388$.

Brzeski W., Kaniuga Z., 1957, Ćwiczenia z biochemii roślin, PWN, Warszawa, wyd. II.

Burström H., 1948, Observations on the influence of galactose on wheat roots, Physiol. Plant. 1:209-215.

C zosnow s k i J., 1962, Metabolism of excised embryos of Lupinus luteus L. II. The water uptake as influenced by osmotic value of the medium, Acta Soc. Bot. Pol. 31:683-691. 
Dormer K. J., Street H. E., 1949, The carbohydrate nutrition of tomato roots, Ann. Boţ. N.S. 13:199-217.

F a rkas G. L., 1954, Die toxische Wirkung einiger Zucker auf die Wurzeln der Pflanzen, Zuckerantagonismen, Biol. Zentralbl. 73:506-521.

Fries N., 1960, The effect of adenine and kinetin on growth and differentiation of Lupinus, Physiol. Plant. 13:468.

Garner N. L., Grann is G. F., 1951, Phosphogalactoisomerase, Science 114: $501-502$.

Gimesi L., Farkas G. L., Pozsar B., Garay A., 1950, Cukrok mérgezö hatása a gyökér meristemáira, Budapesti Tud. Egy. Biol. Inst. Wvk. 1:81-87.

L e e A. E., 1950, The influence of various sugars on the growth in culture of intact seedlings and isolated seedling organs, Am. J. Bot. 37:528-533.

Overbeek van J., Siu H., H a a g e $\mathrm{n}-\mathrm{S}$ m it A. J., 1944, Factors affecting the growth of Datura embryos in vitro, Am. J. Bot. 31:219-224.

Rijven A. H. G. C., 1952, In vitro studies on the embryo of Capsella bursa pastoris, Acta Bot. Neerl. 1:157.

S a s s J. E., 1958, Botanical Microtechnique, Iowa State Coll. Press. Ames.

Slankis V., 1948, Verschiedene Zuckerarten als Kohlehydratquelle für isolierte Wurzeln von Pinus silvestris, Physiol. Plant. 1:278-289.

Stenlid G., 1959, On the effect of some sugars and of 2,4-dinitrophenol upon the absorption of phosphate ions by excised roots, Physiol. Plant 12:199—217.

Stenlid G., 1959, Species differences between plant roots in the reaction to inhibitory sugars, Physiol. Plant. 12:218-235.

Stenlid G., Danckwardt-Lilienström C., 1961, Galactose as a possible source of carbon for the isolated roots of cucumber, Physiol. Plant. 14:671-675.

Street H. E., Lowe J. S., 1950, The carbohydrate nutrition of tomato roots II. The mechanism of sucrose absorption by excised roots, Ann. Bot. 14:307-329.

Szwe y k ow ska A., 1963, The growth response of excised and attached seedling roots to increasing sucrose concentration in the medium. Acta Soc. Bot. Pol. (in press).

Uhvits R., 1946, Effect of osmotic pressure on water absorption and germination of alfalfa seeds, A.m. J. Bot. 33:278-285.

W a l ter H., 1936, Tabellen zur Berechnung des osmotischen Wertes von Pflanzenpressäften und einigen Salzlösungen. Ber. d.d. bot. Ges. 54:328-339.

W h i t e P. R., 1940, Sucrose vs. dextrose as a carbohydrate source for excised tomato roots, Plant Physiol. 15:355-358.

Woods F. W., 1960, Biological antagonismus due to phytotoxic root exudates, Bot. Rev. 26:546-569.

\section{Badania nad wpływem cukrowców na izolowane zarodki Lupinus luteus L. i Brassica oleracea L.}

\section{Streszczenie}

Badano wpływ ośmiu cukrowców na dojrzałe izolowane zarodki łubinu i kapusty $\mathrm{w}$ hodowli in vitro. Hodowlę prowadzono $\mathrm{w}$ ciemności w temp. $25^{\circ} \mathrm{C}$.

Zarodki zarówno łubinu jak i kapusty rozwijają się najlepiej na pożywce z sacharozą jako źródłem węgla. Reakcja zarodków kapusty jest wybitnie dodatnia, zarodków łubinu słabsza. Ta sama różnica w sposobie reagowania występuje na pożywkach z dodatkiem ksylozy, glukozy, fruktozy, maltozy i rafinozy. 
Występuje wyraźna różnica w reakcji hypokotylu i korzenia. Optima dla hypokotylu leżą w zakresie niższych stężeń cukrowców, dla korzeni w zakresie stężeń wyższych. Zarodki łubinu są mniej wrażliwe na wzrastające ciśnienie osmotyczne w pożywce niż zarodki kapusty.

Ani fruktoza, ani glukoza nie są dla zarodków toksyczne, natomiast działanie arabinozy i galaktozy ma wyraźnie toksyczny charakter.

Zarodki lubinu i kapusty różnią się w sposobie reagowania na te same związki podawane w pożywce.

Stwierdzono również wpływ liczby hodowanych w probówce zarodków, zwłaszcza na wzrost korzeni łubinu. U zarodków kapusty zjawiska tego nie stwierdzono. 